\title{
Effectiveness of convective drying to conserve indigenous yeasts with high volatile profile isolated from algerian fermented raw bovine milk (Rayeb)
}

\author{
Latifa HAMOUDI-BELARBI ${ }^{1,2}$, L'Hadi NOURI ${ }^{2}$, Khaled BELKACEMI ${ }^{3 *}$
}

\begin{abstract}
Yeasts Candida tropicalis, Yarrowia lipolytica, Wickerhamomyces anomalus, Issatchenkia orientalis, Kluyveromyces marxianus, Saprochaete suaveolens and Trichosporon coremiiforme were isolated and identified by physiological, biochemical tests with API 20C AUX system and molecular methods by restriction fragment analysis of PCR-amplified 28S-rRNA from Algerian fermented raw bovine milk (Rayeb). Selected yeasts S. suaveolens, I. orientalis, K. marxianus and W. anomalus produced esters and higher esters which can exert a pertinent influence on the sensory characteristics of Rayeb. Viability of S. suaveolens and $W$. anomalus using three methods of drying (freeze-drying, convective drying, and spray-drying) and during 4 months of storage at $4{ }^{\circ} \mathrm{C}$ and $25^{\circ} \mathrm{C}$ in the darkness was studied. Immediately after each drying method, high survival was obtained using freeze-drying followed by convective drying in rice cakes and spray-drying respectively. During storage at $4^{\circ} \mathrm{C}$, convective drying provided better survival of yeast cultures of S. suaveolens and W. anomalus than freeze-drying. At $25^{\circ} \mathrm{C}$ of storage, convective and freeze-dried yeast cultures showed no significant loss of viable cells up to 2 months of storage. Spray-dried yeast cultures had the greatest loss of viable count during the 3 months of storage at $25^{\circ} \mathrm{C}$.
\end{abstract}

Keywords: Rayeb; yeasts; identification; volatile compounds; preservation methods.

Practical Application: Conservation of selected yeasts that produce volatile compounds by convective air drying compared to high cost freeze-drying and spray-drying methods.

\section{Introduction}

Rural communities of Algeria have, for centuries, produced variety of traditional dairy products such as "Rayeb", "Lben", "Jben" and "Smen". These traditional fermented products from untreated raw milk are manufactured with ancestral methods by rural women. Rayeb is the most appreciated in all rural and urban areas of Algeria, Africa and Mediterranean areas (Samet-Bali et al., 2012). Rayeb, produced by spontaneous fermentation of raw milk at ambient temperature for a period of $24 \mathrm{~h}$ to $72 \mathrm{~h}$, has nutritional benefits and plays an important role in the population diet, particularly those of rural population (Idoui et al., 2010). Mixed species of lactic acid bacteria (LAB), Leuconostoc, enterococci, yeasts, especially species of the genera Saccharomyces and Candida as well as moulds are responsible of spontaneous fermentation (Rehaiem et al., 2010). Owing to their proteolytic and lipolytic activities, yeasts represent a significant part in flavoring properties by producing volatile compounds and inducing organoleptic characteristics of Mediterranean areas-fermented milk (Samet-Bali \& Attia, 2012). Few studies are conducted on the identification of yeasts from Algerian Rayeb. Besides, previous studies focused mainly on LAB (Marroki et al., 2011; Idoui \& Karam, 2008).

Yeasts isolated from fermented milk are with high potential desirable technological properties especially in food applications (Grondin et al., 2015). According to the earlier studies showing high performance of S. suaveolens and W. anomalus to produce flavors (Grondin et al., 2015; de Oliveira et al., 2013), they were chosen for conservation by freeze-drying, spray-drying and convective air drying respectively. Freeze-drying and spray-drying are used to conserve potential microorganisms with industrial uses (Miyamoto-Shinohara et al., 2006; Abadias et al., 2005; Cerrutti et al., 2000). These methods offers the convenience related to the storage, transport and handling, and they retain viable microorganisms for a long time periods (Zhu et al., 2016). However, they are relatively costly and require sophisticated equipment and adequate power supply (Santivarangkna et al., 2007). In addition, microorganisms undergo many stresses mainly related to freezing and dehydration during freeze-drying (Coulibaly et al., 2009) and high operating temperatures during spray drying (Atalar \& Dervisoglu, 2015). The low cost convective air drying is an alternative method for microorganism preservation and appeared to be more efficient on cell viability (Nyanga et al., 2012).

The aim of the present study is to address the following three issues: The first deals with identification of some yeasts isolated from Algerian Rayeb using physiological, biochemical tests with API 20C AUX system and molecular methods by restriction fragment analysis of PCR-amplified 28S rRNA. The second allocates to the identification of volatile compounds produced by 
selected yeasts cultivated in bovine raw milk. The last is dedicated to evaluate the convective air drying method in comparison with freeze-drying and spray-drying one to conserve selected yeasts.

\section{Materials and methods}

\subsection{Microorganisms}

Yeasts were isolated from 10 samples of traditional Algerian Rayeb prepared by spontaneous fermentation of whole 10 samples of bovine raw milk from farms located in Algiers region. A volume of $0.1 \mathrm{~mL}$ of each sample was diluted in $9.9 \mathrm{~mL}$ of peptone water solution (Difco, Detroit, USA). After serial dilutions, $1 \mathrm{~mL}$ of aliquots from suitable dilutions was pour-plated in Yeast Extract Glucose agar (YEG agar) prepared using: $10 \mathrm{~g} / \mathrm{L}$ yeast extract (Himedia, Mumbay, India), $20 \mathrm{~g} / \mathrm{L}$ glucose (Sigma, Switzerland), and $20 \mathrm{~g} / \mathrm{L}$ agar (Sigma-Aldrich, Germany). The YEG agar was acidified to $\mathrm{pH} 3.5$ using $100 \mathrm{~g} / \mathrm{L}$ of tartaric acid solution. After incubation at $25^{\circ} \mathrm{C}$ for 5 days, 9 different colonies were randomly selected and purified on YEG agar and stored on the same medium at $4{ }^{\circ} \mathrm{C}$ until their identification.

\subsection{Yeast identification on the basis of physiological and biochemical properties}

The following tests were used: urea hydrolysis, assimilation of different carbon compounds with API 20 C AUX test strips (bioMérieux, Canada Inc.), fermentation of glucose, galactose, maltose, lactose, sucrose and trehalose in Durham tubes containing Yeast Extract Peptone broth (YEP broth) with 2\% of the appropriate sugars, growth at $37^{\circ} \mathrm{C}$, and osmotolerance in $500 \mathrm{~g} / \mathrm{L}$ of glucose and $100 \mathrm{~g} / \mathrm{L}$ of $\mathrm{NaCl}$.

\subsection{DNA extraction}

Yeast cells were grown in YEG broth overnight at $25^{\circ} \mathrm{C}$ and under agitation at $200 \mathrm{rpm}$. Genomic DNA of yeast was extracted with a Miniprep E.Z.N.A Yeast DNA Kit (Omega Bio-tek, Norcross, USA) according to the manufacturer's instructions. In the final step, DNA was eluted in 50-100 $\mu \mathrm{L}$ elution-Buffer preheated to $65^{\circ} \mathrm{C}$ then stored at $-20^{\circ} \mathrm{C}$ until PCR amplification.

\subsection{PCR amplification}

For amplification and sequencing of the nuclear large subunit (LSU) 28S rRNA region, forward primer pairs ITS1 (5'-TCCGTAGGTGAACCTGCGG-3') and ITS4 (5'-TCCTCCGCTTATTGATATGC-3') (Gardes \& Bruns, 1993) were used. Reverse primer pairs LROR (5'-ACCCGCTGAACTTAAGC-3') and LR5 (5'-TCCTGAGGGAAACTTCG-3') were used to amplify D1/D2 region of 28S RNA large subunit (White et al., 1990). The amplification was carried out in $50 \mu \mathrm{L}$ reaction mixture containing $25 \mu \mathrm{L}$ of Ready PCR Mix ( $\times 1$ ) (Amresco, USA). $1 \mu \mathrm{L}$ of each of couple forward and reverse primers (ITS1/ITS4 and LROR/LR5), $10 \mu \mathrm{L}$ gDNA at $5 \mathrm{ng} / \mu \mathrm{L}$ and $13 \mu \mathrm{L}$ of high purity HPLC-grade water and amplification was performed with a total of 30 PCR cycles in a thermal cycler (Mastercycler, Eppendorf, Germany). The cycling program was started with an initial cell lysis at $95^{\circ} \mathrm{C}$ for $4 \mathrm{~min}$ followed by 30 cycles of denaturation at $95^{\circ} \mathrm{C}$ for $30 \mathrm{~s}$, annealing at $55{ }^{\circ} \mathrm{C}$ for $30 \mathrm{~s}$ and elongation at $72^{\circ} \mathrm{C}$ for $1 \mathrm{~min}$. The PCR was ended with a final extension at $72^{\circ} \mathrm{C}$ for $10 \mathrm{~min}$ and the amplified product was stored at $-20^{\circ} \mathrm{C}$. A negative control was performed with each run by replacing the PCR mixture with high purity HPLC-grade water. The quality of PCR products was verified by electrophoresis in $8 \mathrm{~g} / \mathrm{L}$ agarose gel under $90 \mathrm{~V}$ during $45 \mathrm{~min}$, detected by ethidium bromide (EtBr) staining and photographed under UV light with a charge coupled device camera (Sony, Japan). Fragment sizes were determined by using a standard molecular size marker (100 bp ladder, Amresco).

\subsection{Sequencing analysis}

PCR products were purified by adding $150 \mu \mathrm{L}$ of $\mathrm{PB}$ buffer (Qiagen, Mississauga ON), and transferred in the wells of a Whattman GF/C filter plate. Amplified DNA was then washed three times with $80 \mu \mathrm{L}$ of $80 \%$ ethanol/20 mM Tris ( $\mathrm{pH} 7.5$ ) and eluted in $45 \mu \mathrm{L}$ of HPLC-grade water. Samples were quantified using the Quant-iTPicoGreen dsDNA quantification kit (Invitrogen, Carlsbad, CA, USA) using the manufacturer's instructions. DNA sequencing was performed on Applied Biosystems Gene Amp PCR system 9700 (96 or 384 wells) using the BigDye Terminator V.3.1 kit (Applied Biosystems, Foster City, CA, USA). DNA was first denatured by an initial heating step at $96^{\circ} \mathrm{C}$ for $30 \mathrm{~s}$, then cycled using a protocol of 25 cycles of denaturation $\left(96{ }^{\circ} \mathrm{C}\right.$ for $10 \mathrm{~s}$ ) and annealing $\left(53^{\circ} \mathrm{C}\right.$ for $\left.5 \mathrm{~s}\right)$, followed by one last step of elongation $\left(59^{\circ} \mathrm{C}\right.$ for $3 \mathrm{~min}$.). Sequencing reactions were purified by ethanol-EDTA precipitation and re-suspended in HiDiformamide. Samples were then run on an Applied Biosystem Prism 3730xl automated genetic analyzer using $50 \mathrm{~cm}$ capillaries. Sequences were analyzed and edited by Stadden Package version 4.11.2 Primer 3 software (Rosen \& Skaletsky, 1998). The code is available at https://www.broadinstitute.org/genome_software/ other/primer3.html (Broad Institute, 2015). Then, consensus sequences were compared to the GenBank database of NCBI with algorithm BLAST (Blast, 2015).

\subsection{Preparation of strains to GC-MS, extraction and analysis of volatile compounds}

Raw bovine milk was inoculated with preculture of selected yeasts and incubated for $48 \mathrm{~h}$ at $27^{\circ} \mathrm{C}$. Raw bovine milk, fermented raw bovine milk for $24 \mathrm{~h}$, Rayeb-Batch 1 and Rayeb-Batch 2 were used as controls. For each medium, $2 \mathrm{~mL}$-sample of preparation was saturated with sodium chloride $(0.3 \mathrm{~g} / \mathrm{mL})$ for its analysis for volatile compounds. Volatile compounds were analyzed using G1888 Headspace sampler coupled to a HP6890 GC and a 5973N quadrupole MS detector (Agilent Technologies, Wilmington, DE) according to Corcuff et al. (2011).

\subsection{Conservation of selected yeasts}

\section{Production of yeasts}

Production of yeasts was done according to Hamoudi et al. (2007) method. Viable counts before each preservation methods were $6 \times 10^{7} \mathrm{CFU} / \mathrm{mL}$ for S. suaveolens and $2 \times 10^{8} \mathrm{CFU} / \mathrm{mL}$ for W. anomalus. 


\section{Freeze-drying}

After centrifugation at $3000 \times \mathrm{g}$ for $15 \mathrm{~min}$ at $5{ }^{\circ} \mathrm{C}$, harvested cells by were suspended in the protectants solutions $\mathrm{D}(+)$ dihydrate sucrose prepared at $7 \% \mathrm{w} / \mathrm{v}$ with Hydroxyethyl Starch (HES) prepared at 12\% w/v (Sigma Aldrich, St. Louis, Mo., U.S.A.) with demineralized water, and sterilized at $121^{\circ} \mathrm{C}$ for $15 \mathrm{~min}$. After freezing in a freezer for $16 \mathrm{~h}$ at $-25^{\circ} \mathrm{C}$, mixed cells and protectants were freeze-dried in a Unitop $400 \mathrm{~L}$ (Virtis, Gardiner, N.Y., U.S.A.) drying chamber connected to a Freeze-mobile 35 L (Virtis, Gardiner, N.Y., U.S.A.) during $24 \mathrm{~h}$ under vacuum (less than $1 \mathrm{~Pa}$ ).

\section{Convective air drying}

Rice cakes were made by drying rice dough at $40{ }^{\circ} \mathrm{C}$ in a convective air drying oven for $5 \mathrm{~h}$ to reach a moisture content of about $4-5 \% \mathrm{w} / \mathrm{w}$ according to Dung et al. (2005).

\section{Spray-drying}

Cells harvested by centrifugation at $3000 \times \mathrm{g}$ for 15 minutes and at $5{ }^{\circ} \mathrm{C}$ were mixed with whey permeate $(20 \% \mathrm{w} / \mathrm{w})$, previously sterilized at $80{ }^{\circ} \mathrm{C}$ in a water bath for $20 \mathrm{~min}$. Spray-drying was performed in a pilot scale spray-dryer (Niro Atomizer, Denmark). Mixing cells / whey permeate was introduced under sterile conditions into the dryer using a feed pump. The flow rate of the mixture was set at $1 \mathrm{~kg} / \mathrm{h}$; the temperature of the inlet air was at 80 and $90{ }^{\circ} \mathrm{C}$ and the temperature of the outlet air was at 45 and $50{ }^{\circ} \mathrm{C}$.

\section{Storage conditions and enumeration of survivors}

Dried cells from each preservation method were stored at $4{ }^{\circ} \mathrm{C}$ and at $25^{\circ} \mathrm{C}$ in desiccators on silica gel in order to avoid samples rehumidification, in a dark cabinet during 3 months.
Two replications were done for each experiment. After each drying method, enumeration of survivors was done according to Hamoudi et al. (2007) protocole.

\section{Determination of the residual moisture of the dried products}

Residual moisture of the dried products from each drying method was determined in duplicate by the gravimetric method in the vacuum oven at $55^{\circ} \mathrm{C}$ for $48 \mathrm{~h}$ and in the presence of phosphorus pentoxide $\left(\mathrm{P}_{2} \mathrm{O}_{5}\right)$.

\subsection{Statistical analysis}

The experimental data were analyzed using Sigma plot 7 (2001) and Microsoft Office Excel 2007.

\section{Results and discussion}

\subsection{Physiological, biochemical and molecular identification of yeasts}

Plate counts from ten samples of Rayeb showed a yeast load of $2.7 \times 10^{7} \mathrm{CFU} \mathrm{m} / \mathrm{L}$. Table 1 shows the test results of the identified yeast isolates on the basis of urea hydrolysis, assimilation of different carbon compounds using API 20 C AUX, fermentation of chosen sugars, growth at $37^{\circ} \mathrm{C}$, and osmotolerance.

Molecular identification of randomly chosen yeasts from Algerian Rayeb was performed by restriction fragment analysis of PCR-amplified LSU 28S rRNA using forward primers ITS1/ITS4, and D1/D2 region of $28 \mathrm{~S}$ RNA LSU using reverse primers LROR/LR5. PCR amplification profile of yeasts was verified by electrophoresis in agarose gel. Results showed 100\% similarity with sequences in GenBank. Yeasts identified were: Candida tropicalis, Yarrowia lipolytica, Wickerhamomyces anomalus, Issatchenkia orientalis, Kluyveromyces marxianus, Saprochaete.

Table 1. Identification of yeast species isolated from Rayeb by physiological, and biochemical tests with API 20C AUX system.

\begin{tabular}{|c|c|c|c|c|c|c|c|c|}
\hline & Character & C. tropicalis & Y. lipolytica & W. anomalus & I. orientalis & K. marxianus & S. suaveolens & T. coremiiforme \\
\hline \multirow{3}{*}{ 㿣 } & Urea hydrolysis & - & - & - & - & - & - & + \\
\hline & $100 \mathrm{~g} / \mathrm{L}$ of $\mathrm{NaCl}$ & + & - & + & + & - & - & - \\
\hline & $500 \mathrm{~g} / \mathrm{L}$ of Glucose & + & - & + & + & - & - & - \\
\hline \multirow{6}{*}{ 竎 } & Glucose & + & - & + & + & + & + & - \\
\hline & Galactose & + & - & + & - & + & + & - \\
\hline & Sucrose & - & - & + & - & + & - & - \\
\hline & Maltose & + & - & + & - & - & - & - \\
\hline & Lactose & - & - & - & - & + & - & - \\
\hline & Trehalose & + & - & - & - & - & - & - \\
\hline \multirow{10}{*}{ 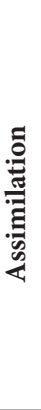 } & Glucose & + & + & + & + & + & + & + \\
\hline & 2-Methyl glucoside & + & + & + & + & - & - & + \\
\hline & Cellobiose & + & - & + & + & + & - & + \\
\hline & Galactose & + & + & + & - & - & + & + \\
\hline & Lactose & - & - & - & - & - & - & + \\
\hline & Maltose & + & - & + & + & + & - & + \\
\hline & Raffinose & - & + & + & + & + & - & - \\
\hline & Mannitol & + & + & + & - & + & - & - \\
\hline & Erythritol & - & + & - & - & - & - & + \\
\hline & 2-Ketogluconate & + & + & - & + & - & - & + \\
\hline
\end{tabular}


suaveolens and Trichosporon coremiiforme. C. tropicalis fermented glucose, galactose, sucrose, maltose and trehalose but not lactose. Lachance et al. (2011) found same results earlier. This yeast has been reported in Ghanaian fermented milk (Akabanda et al., 2013) and Tunisian Leben (Samet-Bali \& Attia, 2012). Y. lipolityca is strictly oxidative, assimilates glucose, galactose, erythritol (Kurtzman et al., 2011) and it was reported as one of the most largely occurring yeast in fermented milk (Johnson \& Echavarri-Erasun, 2011). I. orientalis, that assimilate glucose, is usually found in fermented dairy products because of it proteolytic and lipolytic activities; besides it has been reported to inhibit the growth of Colletotrichum capsicion on the surface of fruits and vegetables (Chanchaichaovivat et al., 2007). W. anomalus that ferments glucose but not disaccharides such as lactose, trehalose and maltose, produced ethyl acetate with antifungal activity against spoilage yeasts (Muccilli \& Restuccia, 2015). K. marxianus, that able to ferment lactose and hydrolyze milk fat, enhanced the survival of Lactobacillus bulgaricus in yoghurt (Liu \& Tsao, 2009).

It is important to highlight the presence of S. suaveolens and T. coremiiforme in Algerian Rayeb because few papers have reported their presence in fermented milk (Bai et al., 2010). Besides, no studies were carried out on the identification of yeasts from Algerian Rayeb. To the best of the authors' knowledge, this is the first comprehensive work on the molecular identification of yeasts prevailing in Algerian Rayeb.

\subsection{Volatile compounds of selected yeasts}

14 volatile compounds were identified by GC-MS and grouped according to chemical families (Table 2). They included 1 alcohol, 4 branched acids, 1 branched aldehyde, 7 esters and 1 terpene. As an example, Figure 1 show a total ion chromatogram (TIC) corresponding to the headspace profiles obtained for fermented raw bovine milk with $S$. suaveolens.

The number of volatile compounds produced by S. suaveolens is higher compared to K. marxianus, I. orientalis and W. anomalus. Indeed, S. suaveolens exhibited about 13 different volatile compounds belonging to branched acids and esters. The number of these volatiles was reduced to $\sim 5$ with $K$. marxianus and to $\sim 3$ with $I$. orientalis, or W. anomalus (Table 2). K. marxianus was characterized by the production of branched acids, esters and little amount of higher esters; however, S. suaveolens was characterized by the production of butanoic acid, ethyl ester and 3-methyl-butanoic acid, ethyl ester. Acetic acid was instead produced by S. suaveolens. Some of these volatile compounds were also produced by $S$. suaveolens in cassava wastewater (Damasceno et al., 2003). Table 3 shows the relative peak area (relative abundance) of the volatile compounds detected in raw bovin milk inoculated with the investigated yeasts. In general, the volatile compounds were characterized by a high proportion of butanoic acid, ethyl ester, followed by 3 methyl-1-butanol, and 3-methyl butanoic acid, ethyl ester. Peak areas of some volatile compounds produced were small except for butanoic acid, ethyl ester produced by S. suaveolens and 3-methyl 1-butanol

Table 2. Volatile compounds produced by raw milk inoculated with S. suaveolens, I. orientalis, K. marxianus, W. anomalus, raw milk, raw milk after 24h of fermentation, Rayeb-Batch 1 and Rayeb-Batch 2 identified by GC retention time and GC-MS analysis.

\begin{tabular}{|c|c|c|c|c|c|c|c|c|c|c|}
\hline $\begin{array}{c}\text { Peak } \\
\text { number }\end{array}$ & $\begin{array}{l}\text { Retention } \\
\text { time (min) }\end{array}$ & Compounds & $\begin{array}{c}\text { S. } \\
\text { suaveolens }\end{array}$ & $\begin{array}{c}I . \\
\text { orientalis }\end{array}$ & $\begin{array}{c}K . \\
\text { marxianus }\end{array}$ & $\begin{array}{c}W . \\
\text { anomalus }\end{array}$ & $\begin{array}{l}\text { Raw } \\
\text { milk }\end{array}$ & $\begin{array}{c}\text { Raw milk } \\
\text { (24h of } \\
\text { fermentation) }\end{array}$ & $\begin{array}{l}\text { Rayeb- } \\
\text { Batch } 1\end{array}$ & $\begin{array}{l}\text { Rayeb- } \\
\text { Batch } 2\end{array}$ \\
\hline & & Primary alcohols & & & & & & & & \\
\hline 1 & & Branched acids & & & & & & & & \\
\hline 2 & 4.68 & Butanoic acid & + & - & - & - & - & - & - & - \\
\hline 3 & 2.58 & Acetic acid & + & + & + & + & - & + & + & + \\
\hline \multirow[t]{2}{*}{5} & 15.71 & Octanoic acid & + & - & - & - & - & - & - & - \\
\hline & & Esters & & & & & & & & \\
\hline 6 & 2.28 & Ethyl acetate & + & + & + & + & - & - & - & + \\
\hline 7 & 3.41 & Butanoic acid, methyl ester & + & - & - & - & - & - & - & - \\
\hline 8 & 4.34 & $\begin{array}{l}\text { 3-methyl-butanoic acid, } \\
\text { methyl ester }\end{array}$ & + & - & - & - & - & - & - & - \\
\hline 11 & 6.06 & $\begin{array}{l}\text { 3-methyl-butanoic acid, } \\
\text { ethyl ester }\end{array}$ & + & - & - & - & - & - & - & - \\
\hline \multirow[t]{2}{*}{12} & 12.02 & $\begin{array}{l}\text { Butanoic acid, } 3 \text { methyl } \\
\text { butyl ester }\end{array}$ & + & - & - & - & - & - & - & - \\
\hline & & Aldehydes & & & & & & & & \\
\hline \multirow[t]{2}{*}{13} & 2.67 & 3-methyl-butanal & - & - & - & - & - & - & - & + \\
\hline & & Terpenes & & & & & & & & \\
\hline 14 & 11.28 & Limonene & + & - & + & - & - & - & - & - \\
\hline
\end{tabular}




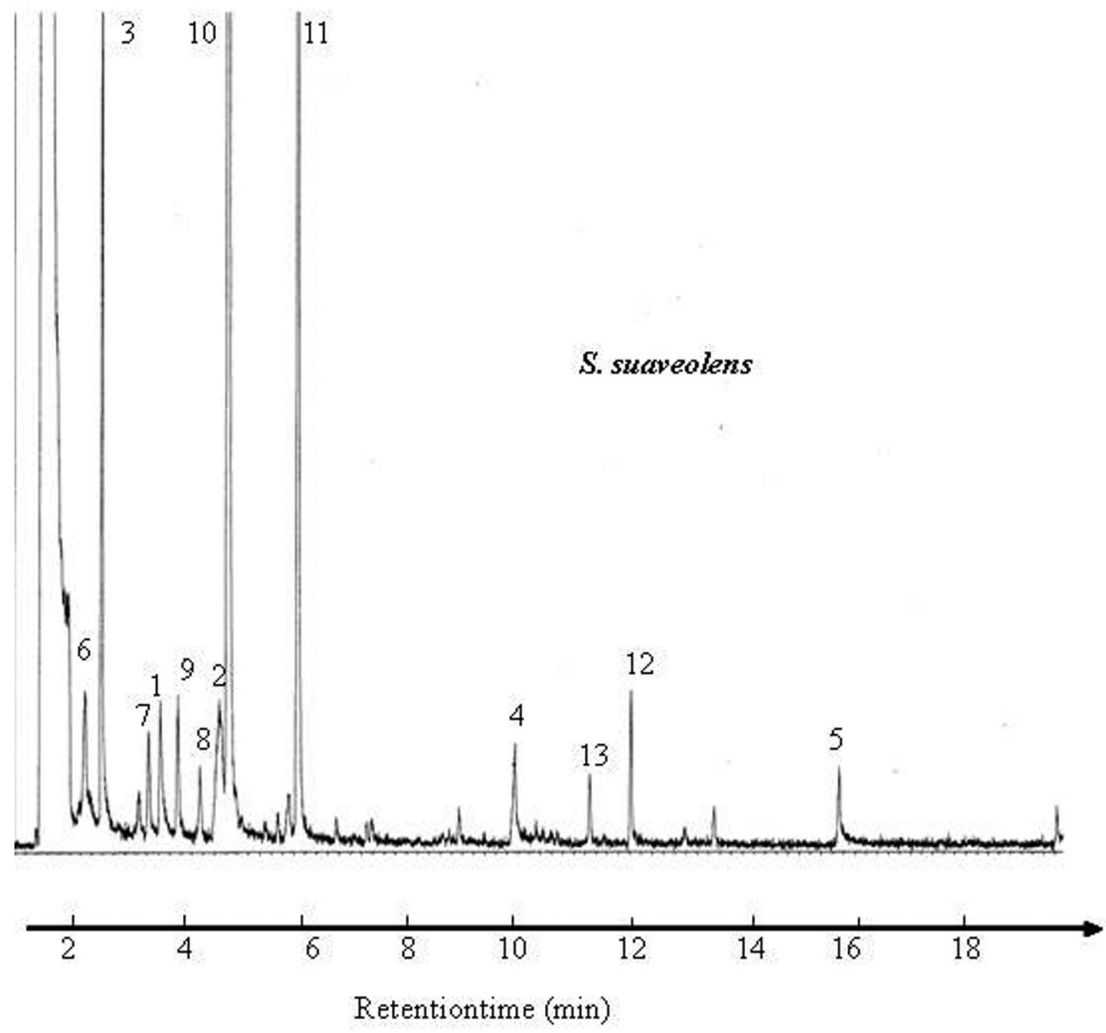

Figure 1. Total ion chromatograms corresponding to the headspace of fermented raw bovine milk with S. suaveolens: (1) 1-Butanol, 3-methyl; (2) Butanoic acid; (3) Acetic acid; (4) Hexanoic acid; (5) Octanoic acid, 3 methylbutyl ester; (6) Ethyl acetate; (7) Butanoic acid, methyl ester; (8) 3-methyl-butanoic acid, methyl ester; (9) 2-methyl-propanoic acid ethyl ester; (10) Butanoic acid, ethyl ester; (11) 3-methyl-butanoic acid, ethyl ester; (12) Butanoic acid, 3 methyl butyl ester; (13) Limonene.

Table 3. Relative peak area (\%) of volatile compounds detected in raw milk inoculated with S. suaveolens, I. orientalis, K. marxianus, W. anomalus, raw milk, raw milk after $24 \mathrm{~h}$ of fermentation, Rayeb-Batch 1 and Rayeb-Batch 2.

\begin{tabular}{|c|c|c|c|c|c|c|c|c|}
\hline Volatile compounds & $\begin{array}{c}\text { S. } \\
\text { suaveolens }\end{array}$ & $\begin{array}{c}I . \\
\text { orientalis }\end{array}$ & $\begin{array}{c}K . \\
\text { marxianus }\end{array}$ & $\begin{array}{c}\text { W. } \\
\text { anomalus }\end{array}$ & Raw milk & $\begin{array}{c}\text { Raw milk } \\
\text { (24h of } \\
\text { fermentation) }\end{array}$ & $\begin{array}{l}\text { Rayeb- } \\
\text { Batch } 1\end{array}$ & $\begin{array}{l}\text { Rayeb- } \\
\text { Batch } 2\end{array}$ \\
\hline \multicolumn{9}{|l|}{ Primary alcohols } \\
\hline 1-Butanol, 3-methyl & $1.33 \pm 0.02^{\mathrm{a}}$ & $33.42 \pm 2.01^{\mathrm{a}}$ & $61.86 \pm 3.10$ & $34.37 \pm 2.10^{\mathrm{a}}$ & - & $33.16 \pm 2.10^{\mathrm{a}}$ & $54.15 \pm 2.20^{\mathrm{a}}$ & $67.29 \pm 3.50^{\mathrm{a}}$ \\
\hline \multicolumn{9}{|l|}{ Branched acids } \\
\hline Butanoic acid & $4.34 \pm 0.20$ & - & - & - & - & - & - & - \\
\hline Hexanoic acid & $1.46 \pm 0.10$ & - & - & - & - & - & - & - \\
\hline \multicolumn{9}{|l|}{ Esters } \\
\hline Ethyl acetate & $1.63 \pm 0.10$ & $26.96 \pm 2.01$ & $7.37 \pm 0.90$ & $35.35 \pm 2.10$ & - & - & - & $4.45 \pm 0.95$ \\
\hline Butanoic acid, methyl ester & $1.29 \pm 0.10$ & - & - & - & - & - & - & - \\
\hline $\begin{array}{l}\text { 3-methyl-butanoic acid, } \\
\text { methyl ester }\end{array}$ & $0.58 \pm 0.02$ & - & - & - & - & - & - & - \\
\hline $\begin{array}{l}\text { 2-methyl-propanoic acid ethyl } \\
\text { ester }\end{array}$ & $1.30 \pm 0.10$ & - & - & - & - & - & - & - \\
\hline Butanoic acid, ethyl ester & $53.80 \pm 2.10$ & - & - & - & - & - & - & - \\
\hline $\begin{array}{l}\text { 3-methyl-butanoic acid, ethyl } \\
\text { ester }\end{array}$ & $24.03 \pm 1.00$ & - & $9.70 \pm 1.00$ & - & - & - & - & - \\
\hline $\begin{array}{l}\text { Butanoic acid, } 3 \text { methyl butyl } \\
\text { ester }\end{array}$ & $1.46 \pm 0.10$ & - & - & - & - & - & - & - \\
\hline \multicolumn{9}{|l|}{ Aldehydes } \\
\hline 3-methyl-butanal & - & - & - & - & - & - & - & $10.53 \pm 1.60$ \\
\hline \multicolumn{9}{|l|}{ Terpenes } \\
\hline Limonene & $0.74 \pm 0.02$ & & $3.22 \pm 0.90$ & & & & & \\
\hline
\end{tabular}

${ }^{2}$ Mean and standard deviation of three repetitions. 
by K. marxianus. Also, 3-methyl-1-butanol was higher in Rayeb issued from Rayeb-Batch 2 sample. This alcohol could be produced by microbial milk spoilage such as Bacillus cereus, Pseudomonas fragi, P. perolens and B. pumilus (Magan et al., 2001).

In general, high levels of butanoic acid, ethyl ester (53.767\%), and 3-methyl-butanoic acid, ethyl ester (24.026\%) were produced by $S$. suaveolens. These volatiles are mostly responsible for the flowery and fruity aroma. Grondin et al. (2015) also described this yeast for production of alcohol and esters compounds. During fermentation, intracellular enzyme catalyzed reactions responsible of the formation of esters (Verstrepen et al., 2003). S. suaveolens produced 3-methyl-butanoic acid, ethyl ester (ethylisovalerate) after partial metabolism of leucine and isoleucine by oxidative deamination and esterification by ethanol (Farbood et al., 1987). It is worth observing that little amount of limonene was produced in raw milk with S. suaveolens or with K. marxianus. Henssen et al. (1984) reported that yeast developed specific fruity odors when associated with bacteria. Aldehydes, such as 3-methyl-butanal were detected in Rayeb. Biosynthesis of this aldehyde is favorable when yeasts are associated with bacteria like Brevibacterium linens (Arfi et al., 2005). According to the results obtained, I. orientalis, K. marxianus especially S. suaveolens and $W$. anomalus with relatively low fermentative activity have high capacity to form volatile compounds such as esters and branched acids as well as higher esters with pleasant aroma.

\subsection{Drying of selected yeasts}

Figure 2 shows the viability of yeast cells of S. suaveolens and $W$. anomalus immediately after freeze-drying, convective air drying and spray respectively.

HES in combination with sucrose provided a light and porous structure of freeze-dried product that made rehydration easy and with moisture content $2.45 \% \pm 1.2$. High levels of viability were observed for freeze-dried S. suaveolens and W. anomalus $(68 \%$ and 74\% respectively). Combination of HES with non-reducing disaccharide sucrose protect algae, protozoa, fungi and bacteria during freeze-drying; often at concentrations ranging from 5 to $15 \%$ (Hubálek, 2003). The mechanism of direct interaction between the sugar molecules and membrane phospholipids is among the main protection mechanisms during freeze-drying (Crowe et al., 1998).

S. suaveolens and W. anomalus with moisture content $4.5 \%$ \pm 0.5 shows high levels of viability ( $60 \%$ and $65 \%$ respectively). These results are in broad agreement with earlier studies showing that convective drying in rice cakes is very effective to conserve S. cerevisiae and I. orientalis yeast strains (Nyanga et al., 2012).

S. suaveolens and W. anomalus with moisture content of 3\% \pm 0.2 gave poor survival values, up to $20 \%$ and $29 \%$ respectively after spray drying. Although, authors reported that, the survival after spray drying depends on the types and concentrations of the encapsulating agent and the inlet air temperature (Atalar \& Dervisoglu, 2015). In this work, processing conditions of spray-drying constant inlet were $80-90{ }^{\circ} \mathrm{C}$. High inlet air temperature causes excessive rapid moisture evaporation, resulting diminution in water activity and cracks in the polymeric membrane of microorganisms (Brun-Graeppi et al., 2011; Telang \& Thorat, 2010).

\subsection{Storage of drying yeasts}

Figure 3 shows the survival results of $S$. suaveolens and W. anomalus after 3 months of storage at $4{ }^{\circ} \mathrm{C}$ (Figure $3 \mathrm{~A}, \mathrm{~B}$ ) and $25^{\circ} \mathrm{C}$ (Figure $\left.3 \mathrm{C}, \mathrm{D}\right)$ in the darkness and on silica gel.

At $4{ }^{\circ} \mathrm{C}$, a drastic decrease in viability of freeze-dried selected yeasts was found at the 1rst 30 days of storage, followed by a stabilization period after 40 days. At the end of storage, the

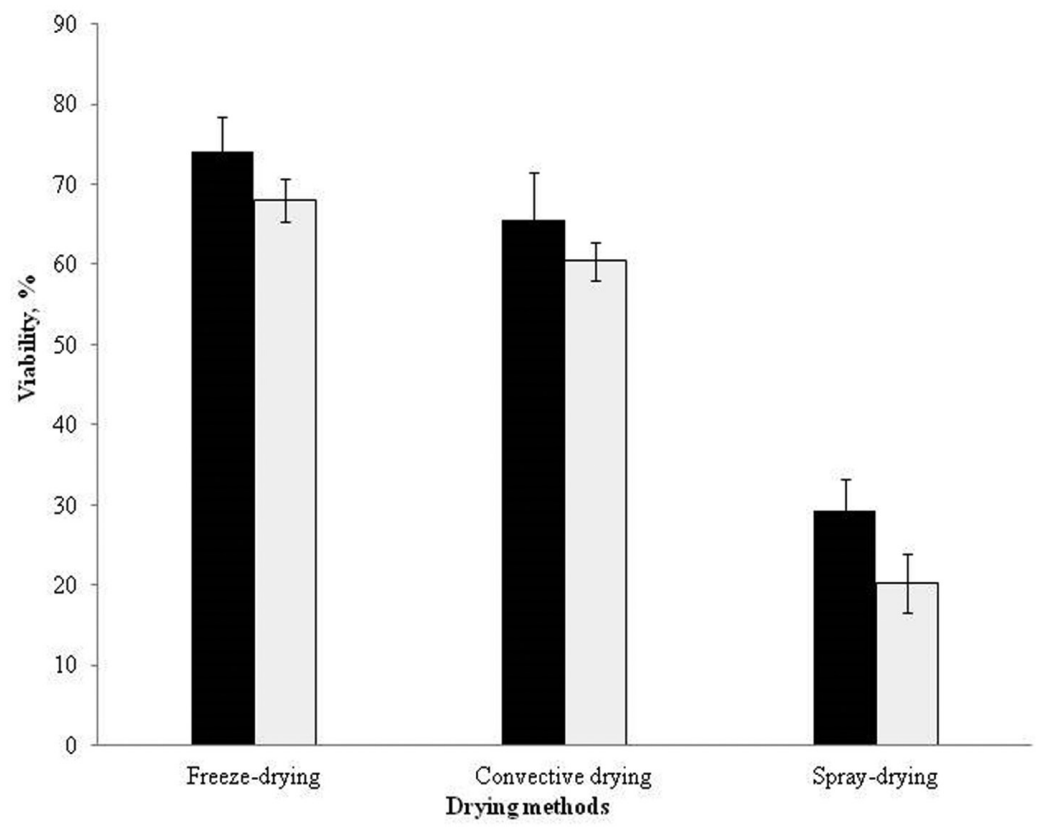

Figure 2. Viability of W. anomalus and S. suaveolens immediately after freeze-drying, convective drying and spray-drying. 

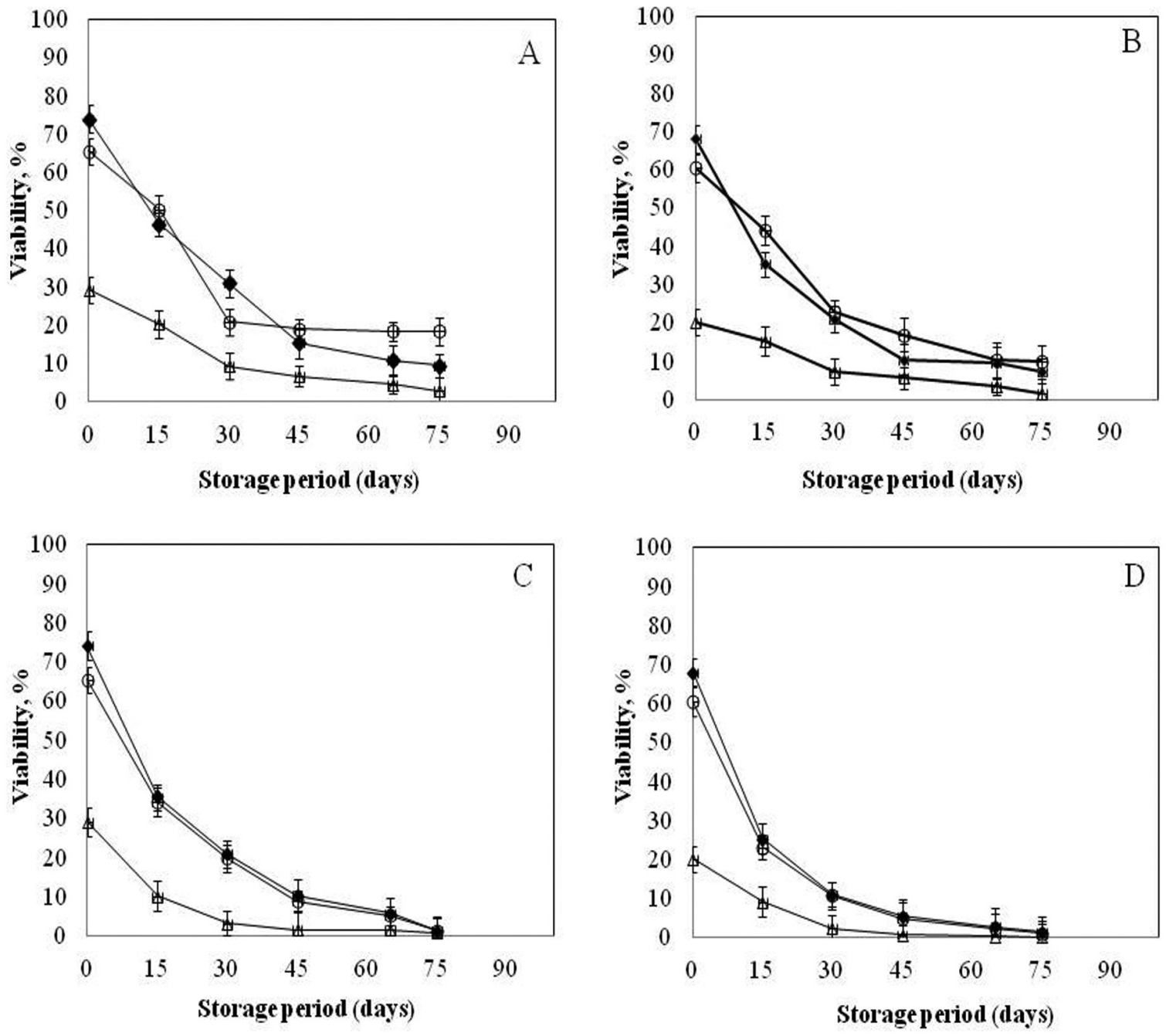

Figure 3. Cell viability of $W$. anomalus and S. suaveolens during storage for 3 month at $4{ }^{\circ} \mathrm{C}(\mathrm{A}, \mathrm{B})$, and $25^{\circ} \mathrm{C}(\mathrm{C}, \mathrm{D})$ on silica gel. $W$. anomalus and $S$. suaveolens cells were dried using $(\bullet)$ freeze-drying, $(\circ)$ convective drying, and $(\Delta)$ spray-drying.

viability of S. suaveolens and $W$. anomalus was stabilized at less than $10 \%$ and $20 \%$ respectively.

As can be seen from Figure 3A, B, a gradual decrease in viability of convective air dried cells was observed; and at the end of storage, viability was maintained at $10 \%$ and $18 \%$. These results demonstrated that, convective air dried yeast cultures retained viability with regard to freeze-drying. Rice contains starch, comprising amylopectin and amylose, could provide the hydroxyl groups in order to fix the yeast cells, and possibly by the formation of a glassy structure, and thus protect the yeast cells damage associated with drying (Nyanga et al., 2012). Spray-dried yeast cells of S. suaveolens and W. anomalus showed a drastic loss of viability during storage and at the end of storage the viability values were less than $5 \%$ approximately for the two yeast strains.

At $25{ }^{\circ} \mathrm{C}$ of storage, the viability decreased at, ultimately reaching at the end of storage values less than $5 \%$, whatever the strain or the drying method being analysed. Costa et al. (2002) found that viability of $P$. agglomerans CPA-2 was maintained for 4 weeks of storage at $4{ }^{\circ} \mathrm{C}$ than at $25^{\circ} \mathrm{C}$. These authors suggested that low temperatures kept the metabolic activities at their lowest level and contribute to stability during storage. Garzon-Rodriguez et al. (2004) found that remaining moisture contribute also to protein degradation.

\section{Conclusion}

Yeasts C. tropicalis, Y. lipolytica, W. anomalus, I. orientalis, K. marxianus, S. suaveolens and T. coremiiforme were randomly isolated and identified from Algerian fermented Rayeb. Selected yeasts S. suaveolens, I. orientalis, K. marxianus and W. anomalus produced different volatile compounds such as branched acids, esters and higher esters with pleasant aroma. Viability of $S$. suaveolens and $W$. anomalus was better immediately after freeze-drying followed by convective air drying in rice cakes and spray drying in whey permeate respectively. During storage at $4{ }^{\circ} \mathrm{C}$, convective air drying provided better survival of selected yeast cultures than freeze-drying. The use of convective air drying to preserve yeasts proves a promising economic alternative to freeze-drying and spray-drying. 


\section{References}

Abadias, M., Teixidó, N., Usall, J., Solsona, C., \& Viñas, I. (2005). Survival of the postharvest biocontrol yeast Candida sake CPA-1 after dehydration by spray-drying. Biocontrol Science and Technology, 15(8), 835-846. http://dx.doi.org/10.1080/09583150500187041.

Akabanda, F., Owusu-Kwarteng, J., Tano-Debrah, K., Glover, R. L. K., Nielsen, D. S., \& Jespersen, L. (2013). Taxonomic and molecular characterization of lactic acid bacteria and yeasts in nunu, a Ghanaian fermented milk product. Food Microbiology, 34(2), 277-283. http:// dx.doi.org/10.1016/j.fm.2012.09.025. PMid:23541194.

Arfi, K., Leclercq-Perlat, M. N., Spinnler, H. E., \& Bonnarme, P. (2005). Importance of curd-neutralising yeasts on the aromatic potential of Brevibacterium linens during cheese ripening. International Dairy Journal, 15(6-9), 883-891. http://dx.doi.org/10.1016/j. idairyj.2004.07.019.

Atalar, I., \& Dervisoglu, M. (2015). Optimization of spray drying process parameters for kefir powder using response surface methodology. LWT-Food Science and Technology, 60(2), 751-757. http://dx.doi. org/10.1016/j.lwt.2014.10.023.

Bai, M., Qing, M., Guo, Z., Zhang, Y., Chen, X., Bao, Q., Zhang, H., \& Sun, T. S. (2010). Occurrence and dominance of yeast species in naturally fermented milk from the Tibetan Plateau of China. Canadian Journal of Microbiology, 56(9), 707-714. http://dx.doi. org/10.1139/W10-056. PMid:20921981.

Blast. (2015). Bethesda: National Center for Biotechnology Information. Retrieved from: http://blast.ncbi.nlm.nih.gov/Blast.cgi

Broad Institute. (2015). Cambridge: Broad Institute. Retrieved from: https://www.broadinstitute.org/genome_software/other/primer3.html

Brun-Graeppi, A. K. A. S., Richard, C., Bessodes, M., Scherman, D., \& Merten, O. W. (2011). Cell microcarriers and microcapsules of stimuliresponsive polymers. Journal of Controlled Release, 149(3), 209-224. http://dx.doi.org/10.1016/j.jconrel.2010.09.023. PMid:21035510.

Cerrutti, P., Segovia, H. M., Galvagno, M., Schebor, C., \& Buera, P. M. (2000). Commercial baker's yeast stability as affected by intracellular content of trehalose, dehydration procedure and the physical properties of external matrices. Applied Microbiology and Biotechnology, 54(4), 575-580. http://dx.doi.org/10.1007/s002530000428. PMid:11092635.

Chanchaichaovivat, A., Ruenwongsa, P., \& Panijpan, B. (2007). Screening and identification of yeast strains from fruits and vegetables: potential for biological control of postharvest chilli anthracnose (Colletotrichum capsici). Biological Control, 42(3), 326-335. http:// dx.doi.org/10.1016/j.biocontrol.2007.05.016.

Corcuff, R., Mercier, J., Tweddell, R., \& Arul, J. (2011). Effect of water activity on the production of volatile organic compounds by Muscodor albus and their effect on three pathogens in stored potato. Fungal Biology, 115(3), 220-227. http://dx.doi.org/10.1016/j. funbio.2010.12.005. PMid:21354528.

Costa, E., Usall, J., Teixidó, N., Torres, R., \& Viñas, I. (2002). Effect of package and storage conditions on viability and efficacy of the freeze-dried biocontrol agent Pantoea agglomerans strain CPA-2. Journal of Applied Microbiology, 92(5), 873-878. http://dx.doi. org/10.1046/j.1365-2672.2002.01596.x. PMid:11972691.

Coulibaly, I., Amenan, A. Y., Lognay, G., Fauconnier, M. L., \& Thonart, P. (2009). Survival of freeze-dried Leuconostoc mesenteroides and Lactobacillus plantarum related to their cellular fatty acids composition during storage. Applied Biochemistry and Biotechnology, 157(1), 7084. http://dx.doi.org/10.1007/s12010-008-8240-1. PMid:18491235.

Crowe, J. H., Carpenter, J. F., \& Crowe, L. M. (1998). The role of vitrification in anhydrobiosis. Annual Review of Physiology, 60(1), 73-103. http:// dx.doi.org/10.1146/annurev.physiol.60.1.73. PMid:9558455.
Damasceno, S., Cereda, M. P., Pastore, G. M., \& Oliveira, J. C. (2003). Production of volatile compounds by Geotrichum fragrans using cassava wastewater as substrate. Process Biochemistry, 39(4), 411414. http://dx.doi.org/10.1016/S0032-9592(03)00097-9.

Dung, N. T. P., Rombouts, F. M., \& Nout, M. J. R. (2005). Development of defined mixed-culture fungal fermentation starter granulates for controlled production of rice wine. Innovative Food Science \& Emerging Technologies, 6(4), 429-441. http://dx.doi.org/10.1016/j. ifset.2005.04.007.

Farbood, M. I., Morris, J. A., \& Seitz, E. W. (1987). Preparation of naturally-occurring C2-C5 alkyl esters of C4-C5 carboxylic acids by means of fermentation of C5-C6 amino acids in the presence of C2-C5 alcohols. U.S. Patent No. 4, 686, 307. Washington, DC: U.S. Patent and Trademark Office.

Gardes, M., \& Bruns, T. D. (1993). ITS primers with enhanced specificity for basidiomycetes: application to the identification of Mycorrhizae and rusts. Molecular Ecology, 2, 113-118. http://dx.doi. org/10.1111/j.1365-294X.1993.tb00005.X.

Garzon-Rodriguez, W., Koval, R. L., Chongprasert, S., Krishnan, S., Randolph, T. W., Warne, N. W., \& Carpenter, J. F. (2004). Optimizing storage stability of lyophilized recombinant human interleukin-11 with disaccharide/hydroxyethyl starch mixtures. Journal of Pharmaceutical Sciences, 93(3), 684-696. http://dx.doi. org/10.1002/jps.10587. PMid:14762907.

Grondin, E., Sing, A. S. C., Caro, Y., Raherimandimby, M., Randrianierenana, A. L., James, S., Nueno-Palop, C., François, J. M., \& Petit, T. (2015). A comparative study on the potential of epiphytic yeasts isolated from tropical fruits to produce flavoring compounds. International Journal of Food Microbiology, 203, 101-108. http://dx.doi.org/10.1016/j. ijfoodmicro.2015.02.032. PMid:25802220.

Hamoudi, L., Goulet, J., \& Ratti, C. (2007). Effect of protective agents on the viability of Geotrichum candidum during freeze-drying and storage. Journal of Food Science, 72(2), 45-49. http://dx.doi. org/10.1111/j.1750-3841.2006.00250.x. PMid:17995841.

Henssen, H. P., Sprecher, E., \& Klingerberg, A. (1984). Accumulation of volatile flavour compounds in liquid cultures of Kluyveromyces lactis strains. Zeitschrift für Naturforschung C, 39, 1030-1033.

Hubálek, Z. (2003). Protectants used in the cryopreservation of microorganisms. Cryobiology, 46(3), 205-229. http://dx.doi. org/10.1016/S0011-2240(03)00046-4. PMid:12818211.

Idoui, T., \& Karam, N. E. (2008). Lactic acid bacteria from Jijel's traditional butter: Isolation, identification and major technological traits. Grasas y Aceites, 59(4), 361-367. http://dx.doi.org/10.3989/ gya.2008.v59.i4.530.

Idoui, T., Benhamada, N., \& Leghouchi, E. (2010). Microbial quality, physicochemical characteristics and fatty acid composition of a traditional butter produced from cows' milk in East Algeria. Grasas $y$ Aceites, 61(3), 232-236. http://dx.doi.org/10.3989/gya.110209.

Johnson, E. A., \& Echavarri-Erasun, C. (2011). Yeast biotechnology. In C. P. Kurtzman, J. W. Fell, \& T. Boekhout (Eds.), The yeasts: a taxonomic study (pp. 21-44). New York: Elsevier.

Kurtzman, C. P., Fell, J. W., \& Boekhout, T. (2011). Summary of species characteristics. In C. P. Kurtzman, J. W. Fell, \& T. Boekhout (Eds.), The yeasts: a taxonomic study (pp. 223-277). New York: Elsevier.

Lachance, M. A., Boekhout, T., Scorzetti, G., Fell, J. W., \& Kurtzman, C. P. (2011). Candida berkhout. In C. P. Kurtzman, J. W. Fell, \& T. Boekhout (Eds.), The yeasts: a taxonomic study (pp. 987-1278). New York: Elsevier.

Liu, S. Q., \& Tsao, M. (2009). Enhancement of survival of probiotic and non-probiotic lactic acid bacteria by yeasts in fermented 
milk under non-refrigerated conditions. International Journal of Food Microbiology, 135(1), 34-38. http://dx.doi.org/10.1016/j. ijfoodmicro.2009.07.017. PMid:19666198.

Magan, N., Pavlou, A., \& Chrysanthakis, I. (2001). Milk-sense: a volatile sensing system recognises spoilage bacteria and yeasts in milk. Sensors and Actuators B, Chemical, 72(1), 28-34. http://dx.doi. org/10.1016/S0925-4005(00)00621-3.

Marroki, A., Zuniga, M., Kihal, M., \& Perez-Martinez, G. (2011). Characterization of Lactobacillus from Algerian goat's milk based on phenotypic, 16S rRNA sequencing and their technological properties. Brazilian Journal of Microbiology, 42(1), 158-171. http:// dx.doi.org/10.1590/S1517-83822011000100020. PMid:24031617.

Miyamoto-Shinohara, Y., Sukenobe, J., Imaizumi, T., \& Nakahara, T. (2006). Survival curves for microbial species stored by freezedrying. Cryobiology, 52(1), 27-32. http://dx.doi.org/10.1016/j. cryobiol.2005.09.002.

Muccilli, S., \& Restuccia, C. (2015). Bioprotective role of yeasts. Microorganisms, 3(4), 588-611. http://dx.doi.org/10.3390/ microorganisms3040588.

Nyanga, L. K., Nout, M. J., Smid, E. J., Boekhout, T., \& Zwietering, M. H. (2012). Yeasts preservation: alternatives for lyophilisation. World Journal of Microbiology \& Biotechnology, 28(11), 3239-3244. http:// dx.doi.org/10.1007/s11274-012-1118-y. PMid:22806747.

Oliveira, S. M. M., Gomes, S. D., Sene, L., Machado, S. R., Coelho, A. C. B., Cereda, M. P., Christ, D., \& Piechontcoski, J. (2013). Production of 2-phenylethanol by Geotrichum fragrans, Saccharomyces cerevisiae and Kluyveromyces marxianus in cassava wastewater. Journal of Food Agriculture and Environment, 11, 158-163.

Rehaiem, A., Martínez, B., Manai, M., \& Rodríguez, A. (2010). Production of enterocin A by Enterococcus faecium MMRA isolated from Rayeb, a traditional Tunisian dairy beverage. Journal of Applied
Microbiology, 108(5), 1685-1693. http://dx.doi.org/10.1111/j.13652672.2009.04565.x. PMid:19840178.

Rosen, S., \& Skaletsky, H. J. (1998). Primer 3. Retrieved from: http:// www-genome.wi.mit.edu/genome software/other/ primer3.html

Samet-Bali, O., \& Attia, H. (2012). Characterization of typical Tunisian fermented milk, Rayeb. African Journal of Biotechnology, 11, 6743-6744.

Samet-Bali, O., Ennouri, M., Dhouib, A., \& Attia, H. (2012). Characterisation of typical Tunisian fermented milk: Leben. African Journal of Microbiology, 6, 2169-2175.

Santivarangkna, C., Kulozik, U., \& Foerst, P. (2007). Alternative drying processes for the industrial preservation of lactic acid starter cultures. Biotechnology Progress, 23(2), 302-315. http://dx.doi.org/10.1021/ bp060268f. PMid:17305363.

Telang, A. M., \& Thorat, B. N. (2010). Optimization of process parameters for spray drying of fermented soy milk. Drying Technology, 28(12), 1445-1456. http://dx.doi.org/10.1080/07373937.2010.482694.

Verstrepen, K. J., Van Laere, S. D. M., Vanderhaegen, B. M. P., Derdelinckx, G., Dufour, J. P., Pretorius, I. S., Winderickx, J., Thevelein, J. M., \& Delvaux, F. R. (2003). Expression levels of the yeast alcohol acetyltransferase genes ATF1, Lg-ATF1, and ATF2 control the formation of a broad range of volatile esters. Applied and Environmental Microbiology, 69(9), 5228-5237. http://dx.doi. org/10.1128/AEM.69.9.5228-5237.2003. PMid:12957907.

White, T. J., Bruns, T., Lee, S., \& Taylor, J. (1990). Amplification and direct sequencing of fungal ribosomal RNA genes for phylogenetics. In M. Innis, D. Gelfand, J. Sninsky, \& T. White (Eds.), PCR protocols: a guide to methods and applications (pp. 315-322). Orlando: Academic Press.

Zhu, Z., Luan, C., Zhang, H., Zhang, L., \& Hao, Y. (2016). Effects of spray drying on Lactobacillus plantarum BM-1 viability, resistance to simulated gastrointestinal digestion, and storage stability. Drying Technology, 34(2), 177-184. http://dx.doi.org/10.1080/07373937.2 015.1021009 . 